\title{
Application Fractography and EDS Analyses for Quality Control of the Castings Made of AlSi7Mg0.3 Aluminium Alloy
}

Lenka Michnova ${ }^{1}$, Ivan Lukac ${ }^{2}$

${ }^{1}$ Faculty of Mechanical Engineering, J. E Purkyne University in Usti nad Labem, Pasteurova 7, 400 01, Usti nad Labem, Czech Republic. E-mail: Lenka.Michnova@ujep.cz,

${ }^{2}$ The Technical University in Košice, Faculty of Metallurgy, Department of Material science, Letna 9, 04200 Kosice, Slovak Republic.E-mail: ivan.lukac@tuke.sk

Fractography is the study of the fracture surface and is concerned with the quantitative and qualitative evaluation of fracture surfaces [1]. It is based on the knowledge of the relationships governing the formation and propagation of fracture areas and is routinely used to determine the cause of failure of forensic engineering or failure analysis [2]. A large majority of casting defects can be detected in the fracture surface. In the technical practice, the formation of a fracture surface represents in most cases the unacceptable stage of mechanical loading or other damage, for instance corrosion damage, of material [3]. Fracture interpretation is a function of the fracture surface condition. The fracture surface contains a wealth of information and it is important to understand them [3] - [9]. Energy-dispersive X-ray spectroscopy (EDS, EDX, or XEDS), is an analytical technique used for the chemical analysis (characterization) of a sample. Accuracy of EDS spectrum can be affected by various factors. The likelihood of an X-ray escaping the specimen, and thus being available to detect and measure depends on the energy of the $x$-ray and the amount and density of material it has to pass through. This can result in reduce accuracy in inhomogeneous and rough samples. The present paper is focused on the possibility fractography to control quality of the castings made of aluminium AlSi7Mg0.3 Alloy to take chance of the tensile test samples.

Keywords: fractography, fracture surface, casting defects, failure analyses castings, $\mathrm{AlSi} 7 \mathrm{Mg} 0,3$ alloy, EDS analyses, metallographic analyses.

\section{References}

[1] LUKAC, I., MICHNA, S.(2014). Colour Contrast, Structure and Defects in Aluminium and Aluminium Alloys. Cambridge International Science Publishing, Cambridge.

[2] www.element.com/.../technicalarticle-fractography

[3] ASM Handbook. (1987) pp. 72 - 77, Vol. 12, Fractography, ASM International.

[4] HULL, D. (1999). Fractography, Observing, Measuring and Interpreting Fracture Surface Topography. Cambridge University Press, New York.

[5] WANG, Q. G. et al. (2001). Fatigue Behaviour of A356-T6 Aluminium Cast Alloys. Journal of Light Metals, Vol. 1, pp. 73-84.

[6] SERIW, M. E. et al. (2000). The Effect of Microscopic Inclusion Location and Silicon Segregation on Fatigue Lifetime of Aluminium Alloy A 356. Castings, Materials Science and Engineering, Vol. 285, pp. 93 - 98.

[7] AVAlle, M. (2002). Casting Defects and Fatigue Strength of a Die Cast Aluminium Alloy: a Comparison Between Standard Specimens and Production Components. International Journal of Fatigue, Vol. 24, pp. 101 107. Netherlands.

[8] WANG, J. et al. (2002). Effect of Melt Thermal Treatment on Hypoeutectic Al-Si Alloys. Material Science and Engineering, Vol. 338, pp. $101-107$. Netherlands.

[9] AKTAR, S. et al. (2011). A Comparative Study of Defects and Mechanical Properties in High Pressure Die Cast and Gravity Die Cast Aluminium Alloys. FTJ, pp. 348 - 356.

[10] DAHLBERG, E. P. Fractography: An Important Tool for Analyzing Failures. Element Houston. www.element.com.

[11] MIRZAEI, B. (2011). Oxide Hydrogen Interaction and Porosity Development in Al-Si Alloys. Norwegian University of Science and Technology, Norway.

[12] CAMPBELL, J. (2003) Castings. Butterworth - Heinemann, Massachusetts. 0-7506-4790-0.

[13] ENGH, T. A. (1992). Principles of Metal Refining. Oxford University Press, Oxford.0-19-856337-X.

[14] MORI, A. (2010). Empirical Models of Mechanical Behaviour of Al-Si-Mg Cast Alloys for High Performance Engine Applications. Metallurgical Science and Technology, Vol. 28-2, pp. 1- 8. Carmagnola, Italy.

[15] DISPINAR, D. (2005). Metal Quality of Aluminium and Its Alloys. PhD thesis, The University of Birmingham.

[16] SREJA KUMARI, S. S. (2006). Influence of Alloying Additions of the Structure and Properties of AlSi7Mg0,3 Alloys. Cochin University of Science and Technology, PhD thesis, India. 